\title{
Мікрохірургічні методики в лікуванні дефектів тканин, спричинених бойовою травмою
}

\author{
С. П. Галич, Я. П. Огородник, О. Ю. Дабіжа, О. А. Гиндич
}

Національний інститут хірургії та трансплантології імені О. О. Шалімова НАМН України, м. Київ

\section{Microsurgical cryosurgical procedures in treatment of the tissues defects, caused by military operational trauma}

\author{
S. P. Galych, Ya. P. Ogorodnyk, O. Yu. Dabizha, O. A. Gyndych
}

Shalimov National Institute of Surgery and Transplantology, Kyiv

Реферат

Мета. Проаналізувати застосування мікрохірургічних методик у лікуванні великих дефектів тканин, що виникли внаслідок бойових поранень, та післяопераційні ускладнення 3 тим, щоб покращити умови для подальшої реабілітації постраждалих.

Матеріали і методи. За період з 2015 по 2018 р. лікували 65 військовослужбовців Збройних Сил України, інших силових відомств та добровольчих батальйонів, яким застосовували переміщення та пересадку васкуляризованих комплексів тканин для закриття дефектів тканин голови, верхніх та нижніх кінцівок, черевної стінки, промежини, іншої локалізації. Результати. У жодному спостереженні реконструктивне лікування не ускладнилось тотальною втратою клаптя або кінцівки.

Висновки. Мікрохірургічне переміщення або пересадка васкуляризованих комплексів тканин є методом вибору, а іноді і єдиним методом хірургічного лікування дефектів тканин, спричинених бойовою травмою.

Ключові слова: дефект тканин; бойова травма; реконструкція; васкуляризовані комплекси тканин.

Abstract

Objective. To analyze the application of microsurgical procedures in the treatment of large defects of tissues, which have occurred as a consequences of military woundings and postoperative complications, and to improve the conditions for further rehabilitation of the injured persons.

Materials and methods. In 2015 - 2018 yrs to 65 members of the Armed Forces of Ukraine, other security institutions and volunteer battalions a transposition or transplantation of the tissues vascularized complexes were applied for closure of the tissues defects of the head, upper and lower extremities, abdominal wall, perineum, and other localization.

Results. In no one observation a reconstructive treatment was complicated by total loss of the flap or extremity.

Conclusion. Microsurgical transposition or transplantation of vascularized complexes of tissues constitutes a method of choice, and sometimes the only one, in surgical treatment of the tissues defects, caused by military operational trauma.

Keywords: defect of tissues; military operational trauma; reconstruction; vascularized complexes of tissues.

За даними Генерального штабу Збройних Сил України з початку проведення антитерористичної операції на сході нашої країни поранено понад 8 тисяч військовослужбовців. Згідно з інформацією Міжнародного Червоного Хреста, поранення в «гарячих точках» мають такий характер: уламкові (46\% спостережень), кульові (26\%), підриви на мінах (23\%), опіки 2\%. У 3\% спостережень причини поранень залишаються невстановленими. Частота поранень кінцівок становить 66\%, голови або шиї - 12\%, грудної клітки - 7\%, черевної порожнини - 6\% [1]. Дефекти тканин, що виникають внаслідок поранень у ході бойових дій, істотно відрізняються від дефектів тканин, що виникають в мирний час. Поранені з мінно-вибуховою, кульовою та уламковою травмою потребують етапної кваліфікованої спеціалізованої допомоги. Використання стандартних методик лікування, таких як пластика місцевими тканинами, філатовським стеблом, шкірна пластика, загоєння вторинним натягом, доцільно лише у разі невеликих дефектів тканин. Обтяжують лікування контузія тканин поза зоною візуальних пошкоджень, порушення мікроциркуляції тканин на фоні збереженого магістрального кро- вотоку, антибіотикорезистентна мікрофлора в рані. В лікуванні великих дефектів тканин лише застосування мікрохірургічних клаптів забезпечує хорошу васкуляризацію з низькою частотою післяопераційних ускладнень [2]. Аналіз повідомлень про результати лікування бойових поранень, отриманих в інших військових конфліктах світу, вказує на незаперечні переваги застосування васкуляризованих комплексів тканин у постраждалих з пошкодженнями різної локалізації [3, 4].

Мікрохірургічні методики дають можливість зменшити ризик ускладнень та покращити подальшу фізичну реабілітацію поранених [5, 6].

Мета дослідження: проаналізувати застосування мікрохіругічних методик у лікуванні великих дефектів тканин, що виникли внаслідок бойових поранень, післяопераційні ускладнення з тим, щоб покращити умови для подальшої реабілітації постраждалих.

\section{Матеріали і методи дослідження}

За період з 2015 по 2018 рік в Інституті ліковали 122 військовослужбовці Збройних Сил України, інших сило- 


\begin{tabular}{|c|c|c|c|}
\hline \multicolumn{4}{|c|}{$\begin{array}{l}\text { Комплекси тканин, які застосовували для } \\
\text { реконструктивного лікування поранених }\end{array}$} \\
\hline \multirow[b]{2}{*}{ Клапоть } & \multicolumn{2}{|c|}{ Реконструктивне лікування } & \multirow[b]{2}{*}{ Усьoro } \\
\hline & $\begin{array}{l}\text { мікросудинне } \\
\text { переміщення }\end{array}$ & $\begin{array}{c}\text { вільна } \\
\text { пересадка }\end{array}$ & \\
\hline Лобний & 1 & - & 1 \\
\hline Ліктьовий передпліччя & 2 & - & 2 \\
\hline $\begin{array}{l}\text { Пропелерний } \\
\text { перфорантний } \\
\text { променевої артерії }\end{array}$ & 3 & - & 3 \\
\hline Трапецієподібний & 3 & - & 3 \\
\hline Торакодорзальний & 7 & 3 & 10 \\
\hline Прямого м'яза живота & 5 & - & 5 \\
\hline $\begin{array}{l}\text { М'яза-натягувача } \\
\text { широкої фасції стегна }\end{array}$ & 7 & - & 7 \\
\hline Прямого м'яза стегна & 3 & - & 3 \\
\hline $\begin{array}{l}\text { Передньо- } \\
\text { латеральний стегна }\end{array}$ & 2 & - & 2 \\
\hline $\begin{array}{l}\text { Підошовний шкірно- } \\
\text { фасціальний }\end{array}$ & 3 & - & 3 \\
\hline $\begin{array}{l}\text { Рандомізовані } \\
\text { перфорантні }\end{array}$ & 8 & - & 8 \\
\hline Разом ... & 44 & 3 & 47 \\
\hline
\end{tabular}

вих відомств та добровольчих батальйонів, із них 65 - у відділенні мікросудинної, пластичної та відновлювальної хірургіï. Період від отримання поранення до госпіталізаціі тривав від 6 днів до 2,5 місяця. У 83\% госпіталізованих поранення були множинними та поєднаними, у 17\% - ізольованими. Усі хворі - чоловіки у віці від 17 до 53 років. У 12 хворих із пошкодженнями кінцівок попередньо в невідкладному порядку відновлювали магістральний кровоток. На момент госпіталізації на інших етапах лікування хворим було виконано в середньому 4 операції (від 2 до 11).

Мікрохірургічні методики, такі як переміщення та вільна пересадка васкуляризованих клаптів, застосували для закриття дефектів тканин верхніх кінцівок у 28 хворих, нижніх - у 9, черевної стінки та промежини - у 15, голови - у 1, іншої локалізації - у 12.

До операції, окрім стандартних клінічних обстежень, хворим проводили ультразвукове дуплексне сканування,

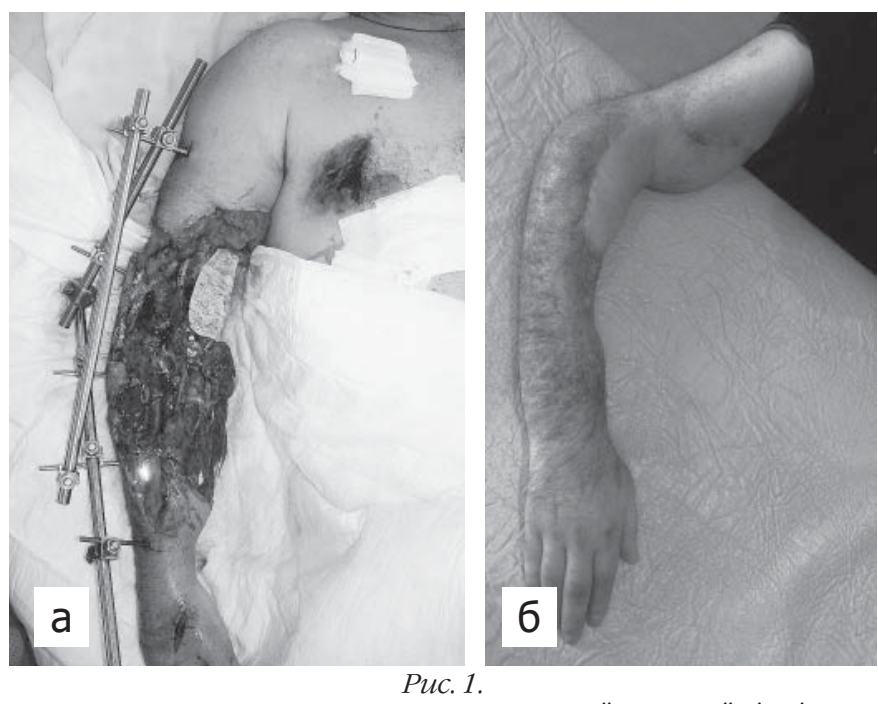

а -велика рвано-розчавлена рана правої верхнъої кінцівки, отримана внаслідок вибуху міни; б - вигляд верхнъої кінцівки після хірургічного лікування. мультиспіральну комп'ютерну та магнітно-резонансну томографію, ангіографію.

Весь період лікування таких хворих умовно можна поділити на три етапи. На першому етапі проводили заходи із загально-клінічної стабілізації стану поранених, лікували гнійно-септичні ускладнення, виконували невеликі за обсягом оперативні втручання (вторинну хірургічну обробку ран, накладення провізорних швів, видалення некротизованих тканин тощо). На другому етапі виконували великі за обсягом оперативні втручання - реконструкцію, закриття значних дефектів покривних тканин за допомогою мікросудинної пересадки або транспозиції складних комплексів тканин, відновлення пошкоджених нервових стовбурів, сухожилків, кісток, відновлюючи функцію пошкоджених ділянок. На третьому етапі застосовували методи пластичної естетичної хірургії та фізіотерапевтичне лікування для покращення естетичного вигляду пошкоджених ділянок.

Для закриття дефектів тканин пораненим виконали мікросудинне переміщення 44 та вільну пересадку 3 васкуляризованих клаптів. Перевагу віддавали переміщенню як технічно більш простій методиці з нижчою частотою гемодинамічних ускладнень (див. таблицю). Наводимо спостереження.

Хворий У., 1970 р. н., госпіталізований у відділення з діагнозом: мінно-вибухова травма; травматична хвороба; велика рвано-розчавлена рана правої верхньої кінцівки з ураженням судин, стан після протезування плечової артерії; косий відкритий перелом діафізу правої променевої кістки; стан після металоостеосинтезу; закрита черепно-мозкова травма; струс головного мозку; респіраторний дистрес-синдром, забій легенів; проникаюче поранення правого ока; чужорідне тіло орбіти; множинні непроникаючі уламкові й опікові поранення обличчя, грудної клітки, калитки, правого стегна (рис. 1a).

Відмітили неповну травматичну ампутацію кінцівки з ризиком їі втрати через тромбоз судинного протеза чи арозивну кровотечу. Дефект займав всю долоневу поверхню, плече та передпліччя, його максимальна довжина дорівнювала 41 см. Окрім покривних тканин, були пошкоджені плечова кістка, сухожилки, м'язи та нервові стовбури кінцівки. Стан хворого та кінцівки ускладнювали контузія тканин навколо дефекту, ранова інфекція та уламкові пошкодження іншої локалізаціі. Жодна інша методика, окрім мікрохірургічної, не могла забезпечити закриття такого дефекту.

Після стабілізації загального стану хворого виконали мікросудинну транспозицію торакодорзального клаптя. Через розміри дефекту клапоть був забраний у своїх максимальних параметрах. Фрагментом клаптя найширшого м'яза спини замістили частину травмованого двоголового м'яза плеча, чим суттєво покращили функцію кінцівки. Середню і дистальну третини передпліччя додатково закрили поліуретановим синтетичним покриттям.

У подальшому виконали демонтаж стрижневого апарата зовнішньої фіксації, фасціотомію з декомпресією відділу розгиначів передпліччя, аутодермопластику гранулюючої рани передпліччя та видалення уламка міни. Отримані задовільні функціональні та естетичні результати лікування (рис. 1б). 

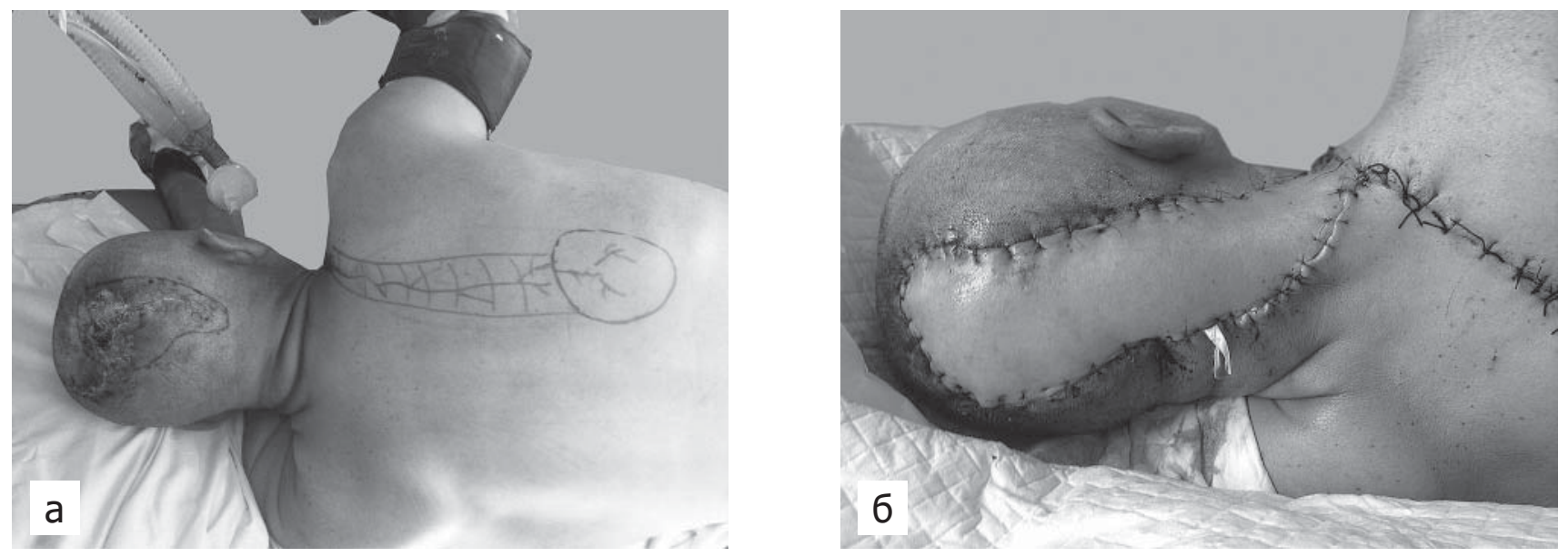

Puc.2.

a - дефект потилично-тім'яної ділянки голови та доопераційна розмітка трапецієподібного клаптя спини; б - дефект потилично-тім'яної ділянки голови закритий трапецієподібним клаптем спини.

Хворий Г., 1969 р. н., госпіталізований з діагнозом: дефект покривних тканин голови, потиличної та тім'яної кісток, твердої мозкової оболонки, тканини мозку; лікворея.

Після стабілізації загального стану пацієнта спільно 3 нейрохірургами видалили нежиттездатні частини покривних, кісткової та мозкової тканин потилично-тім'яної ділянки. Дефект твердої мозкової оболонки закрили фрагментом широкої фасції стегна. Через контузію навколишніх тканин умов для проведення вільної мікрохірургічної пересадки клаптів не було. Тому, враховуючи великі розміри дефекту, для його заміщення виконали мікросудинну транспозицію трапецієподібного клаптя спини (рис.2a).

Дефекти донорської та реципієнтної ділянок вдалося закрито первинно (рис. 2б). У подальшому здійснювали корекцію переміщеного клаптя 3 хорошим естетичним результатом.

\section{Результати}

Після операції за хворими спостерігали в середньому 92 дні. Післяопераційні ускладнення виникли у 31 (48\%) хворого. Усі ускладнення розподілили на ранні - 21 (33\%) хворий та пізні - 10 (15\%) хворих. Серед ранніх ускладнень були гематома (9 спостережень), серома (2), нагноєння післяопераційної рани (7), транзиторні порушення кровопостачання клаптя (3); пізніх - частковий некроз переміщених клаптів (4) та функціональні розлади реципієнтної та донорської ділянок, що потребували коригуючого лікування (6).

У жодного пацієнта не відмічали тотальної втрати клаптя чи кінцівки. Кожному хворому виконали в середньому 3 реконструктивні та/або коригуючі операції (від 1 до 8)

\section{Обговорення}

Особливістю пацієнтів з мінно-вибуховою травмою $є$ одночасне пошкодження кількох анатомічних ділянок, комбінованість та поєднаність різних видів пошкоджень, триваліший період лікування у порівнянні з пацієнтами з дефектами тканин, отриманими в мирний час. Такі хворі потребують тривалої медичної та соціальної реабілітації. Пошкодження кінцівок характеризуються значною варі- абельністю клінічних проявів та вираженою інвалідизацією. У хворих з пошкодженнями верхньої кінцівки для закриття дефектів найчастіше використовували переміщення перфорантного пропелерного та ліктьового клаптів передпліччя, а також переміщення та пересадку торакодорзального клаптя спини, у хворих із пошкодженнями нижньої кінцівки - переміщення клаптя м'яза - натягувача широкої фасції стегна, прямого м'яза стегна, передньо-латерального клаптя стегна та підошовного шкірно-фасціального клаптя.

Пошкодження в ділянці черевної стінки та промежини часто поєднані із пошкодженням кишечника, органів урогенітальної ділянки та мають великий ризик бактеріального забруднення. Для закриття дефектів даної локалізації найчастіше застосовували переміщення клаптя прямого м'яза живота та клаптя м'яза - натягувача широкої фасції стегна. Соціальна та психологічна адаптація цієї групи хворих складна.

Хворі з проникаючими пошкодженнями та дефектами тканин голови потребують допомоги нейрохірургів, отоларингологів, офтальмологів, щелепно-лицевих хірургів як на доопераційному етапі, так і під час операції. Для закриття дефектів тканин голови найчастіше застосовували переміщення трапецієподібного та лобного клаптів.

Високу частоту ранніх післяопераційних ускладнень можна пояснювати погіршенням репаративних процесів та кровопостачання тканин внаслідок їх контузії, коли пошкодження поширюються за межі видимого дефекту. Ми вважаємо, що для досягнення хороших функціональних результатів лікування важливо проводити лікувальну фізкультуру, масаж, розробляти пошкоджені ділянки, застосовувати фізіотерапевтичні процедури (електрофорез, магнітолазер, електронейроміостимуляція) одразу після реконструктивного лікування. Комбінуючи вказані методи лікування, ми досягли у переважної більшості хворих хороших та задовільних результатів.

\section{Висновки}

1. Методом вибору, а іноді і єдиним методом хірургічного лікування наслідків мінно-вибухових та вогнепальних поранень з утворенням великих дефектів тканин є мі- 
крохірургічне переміщення або пересадка васкуляризованих комплексів тканин.

2. Основною причиною післяопераційних ускладнень $€$ порушення кровопостачання навколишніх тканин та їх ураження внаслідок контузіі.

3. Для досягнення хороших функціональних та естетичних результатів лікування необхідно поєднувати хірургічні та нехірургічні методи.

\section{References}

1. Berezka MI, Lytovchenko VO, Vlasenko VH, Naumenko VO, Hariachyi YeV, Spesyvyi II. Khirurhiia viiskova ta nadzvychainykh sytuatsii. Metodychni vkazivky dlia studentiv. Kharkiv: KhNMU; 2013.1 25. [In Ukrainian].

2. Sabino J, Tintle S, Martin B, Howard R, Fleming M, Valerio I. Review of pedicled groin and thoracoepigastric flaps in war-related extremity trauma. Plast Reconstr Surg Supplement. 2015;136:10-1. doi: 10.1097/01 prs.0000472284.09084.2b.

3. Valerio I, Sabino J, Tintle S, Fleming M, Howard R, Basile P, et. al. Multiple flap limb salvages within same war wounded casualties: a consecutive case series over a decade of war trauma. Plast Reconstr Surg Abstracts. 2012;130:92-3. doi: 10.1097/01.prs.0000421808.32111.18

4. Sabino J, Johnson ON, Martin BD. Extremity reconstruction outcomes war related trauma. 91st Annual meeting of American association of plastic surgeons. 2012; San Francisco, California.

5. Sabino J, Polfer E, Tintle S, Jessie E, Fleming M, Martin B, et. al. A decade of conflict: flap coverage options and outcomes in traumatic warrelated extremity reconstruction. Plast Reconstr Surg. 2015;135:895902. doi: 10.1097/PRS.0000000000001025

6. Ucak M, Ulutas KT. Bone allograft and transposition flap reconstruction for a gunshot wound of mandible in Syria civil war. Plast Reconstr Surg. Abstracts. 2015;136:437. doi: 10.1097/01.prs.0000470121.03369.d0 